\title{
Construction on Information Security System for Internet Finance
}

\author{
Wenfang Cao \\ Business School, Wuhan Polytechnic, Wuhan, 430074, China
}

83202208@qq.com

Keywords: internet finance; information security system; construction; risk; strategies

\begin{abstract}
Internet finance is an organic combination of Internet and finance. At the same time, it also has serious information security risk, which brings great challenges to the development of Internet finance. It is imminent to build an information security system that meets the requirements of Internet finance. Based on the analysis of Internet financial information security risk, this paper constructs the Internet system composed of eight branch systems, such as organization system, evaluation system, technical system, management system, legal system, standard system, running system and monitoring system of Internet financial information security. Financial information security system, put forward to protect the Internet financial information security strategy, fundamentally protect the rapid development of Internet finance.
\end{abstract}

\section{Introduction}

Network information security is not due to accidental or malicious factors, so that the network information subject to illegal tampering, insert, delete or show to ensure the integrity of the information, confidentiality and usability. With the extensive application and rapid development of network technology, the network has become the infrastructure of modern information society. Computer network has the characteristics of connection diversity, terminal distribution inhomogeneity, network openness and interconnection. The network has become an important tool for information exchange and various social activities, and has penetrated into various fields of social life. Due to the influence of computer virus spread, network hacking and computer network crime, the network security problem becomes more and more serious, and the network information security has become a common concern.

Internet finance is a new type of financial business model in which traditional financial institutions and Internet companies use the Internet and information and communication technology to realize financial intercourse, payment, investment and information intermediary services. The deep integration of the Internet and finance is a general trend, the financial products, business, organization and services have a profound impact. Internet finance is not a simple combination of the Internet and the financial industry, but based on security and mobile and other network technology, users are familiar with and accepted, to adapt to new needs arising from the new model and new business. As the Internet finance based on the network, so that the financial business with a "strong transparency, high participation, good collaboration, low intermediate cost, easy operation" and other characteristics. Promote the healthy development of Internet finance, help to improve the quality and efficiency of financial services, deepen financial reform, promote financial innovation and development, expand the financial industry open, build multi-level financial system. As a new thing, Internet finance needs both market-driven, encourage innovation, and need policy help to promote development.

Internet finance relies on virtualized service, fuzzy business boundaries, open operating environment and transparent market operation mechanism, and constantly expand the breadth and depth of Internet services to promote financial products and services innovation to meet the growing heterogeneity Financial needs, is creating a wealth of another miracle. Information security is the prerequisite and guarantee for the development of Internet financial stability. However, the Internet financial development depends on the information technology and management level is relatively 
backward, information security, risk and supervision and other issues more and more prominent, seriously restricting the development of Internet finance. Information security system is the organization in accordance with the relevant standards of information security management, the development of information security management principles and strategies, the use of risk management methods, information security management planning, implementation, review, inspection and improvement of the working system. Facing the ever-changing pace of development of Internet finance, it is imminent to build an information security system that meets the requirements of Internet finance. This paper aims at the Internet financial information security risk, the construction of Internet financial information security system to protect the health, stability and rapid development of Internet finance.

\section{Information Security Risk For Internet Finance}

With the continuous development of Internet finance, new technologies and new business forms continue to appear at the same time, also faced with increasingly serious information security risks, highlighted in six aspects, as shown in Fig.1 [1-4].

\begin{tabular}{|c|c|}
\hline \multicolumn{1}{|c|}{ Information security risk for internet finance } \\
\hline Data information risk & \\
\hline Core technology risk & Outsourcing management risk \\
\hline Transaction process risk & Internal control risk \\
\hline
\end{tabular}

Fig. 1. Information security risk for internet finance

(1) Data information risk. Internet finance is based on the data center, cloud computing and large data based on the information mining, analysis and sharing, the purpose is to achieve scientific prediction and reasonable judgments. With the explosive growth of trading volume, practitioners to the customer online and offline transactions and other aspects of information widely collected through the relevant mathematical model for scientific analysis. The improper management of these massive information, will cause the customer's personal privacy information "leak and loss."

(2) The core technology risk Core technology risk. Internet financial information system, many high-end equipment and core software are from abroad, the lack of independent intellectual property rights with the hardware and management software, system development and integration of poor, there are two main types of risks: First, the technical application of risk, the design concept of one-sidedness and limitations of the technical system caused by obvious defects; Second, the technical capacity of the risk, the Internet financial platform for technical defects, leading to inevitable risks.

(3) The transaction process risk. Mainly include three categories: First, the two sides of the transaction credit, network financial transactions using the virtual network, there are contracts due to not fully fulfill the obligations of the problem; second, liquidity, Financial institutions reserve funds is not enough to redeem the customer needs, the amount of money is less than the amount of customer electronic money; Third, payment and settlement, the financial network of open features, determines the payment and settlement of globalization, network problems will be Causing serious losses.

(4) Outsourcing management risk. Due to the strong technical expertise of Internet technology, it needs a lot of research input. At the present stage, some Internet financial enterprises, from the point of view of cost saving, adopt technology outsourcing strategy to provide business or technology for enterprises Support, do not have the core technology of enterprise operation, so there are two types of risks: first, there may be unable to meet the needs of the technical support risks; second, will not outsource the core business outsourcing, data leakage risk.

(5) Internal control risk. Most Internet financial institutions will focus on strategic tasks on business development, to seize the market share as the starting point, focusing on product 
development and application, but in the risk prevention and internal control construction is lagging behind The Internet Financial Services Internal control risks are often associated with inappropriate operations and internal control procedures, information system failures, and human errors, which can lead to unpredictable losses when internal controls and information systems are defective.

(6) Emergency handling is a process that deals with the dangers of major accident disasters, including pre - prevention, incidental coping, disposition and rehabilitation. Most of the Internet financial institutions, in the system construction and operation process, especially for systems that are not included in $\mathrm{P} 2 \mathrm{P}$ and other institutions, there is no well-developed emergency contingency plan to deal with disasters such as electricity, earthquakes and floods. The occurrence will cause huge losses.

\section{Information Security System for Internet Finance}

The construction of Internet financial information security system is a systematic project of planning, management and technology. It is a dynamic process of continuous development. It is composed of a number of branch systems, interdependent and support each other to jointly guarantee the security of Internet financial information. With reference to the relevant literature [4-8], this paper constructs the Internet financial information security system, which consists of eight branch systems, as shown in Fig. 2.

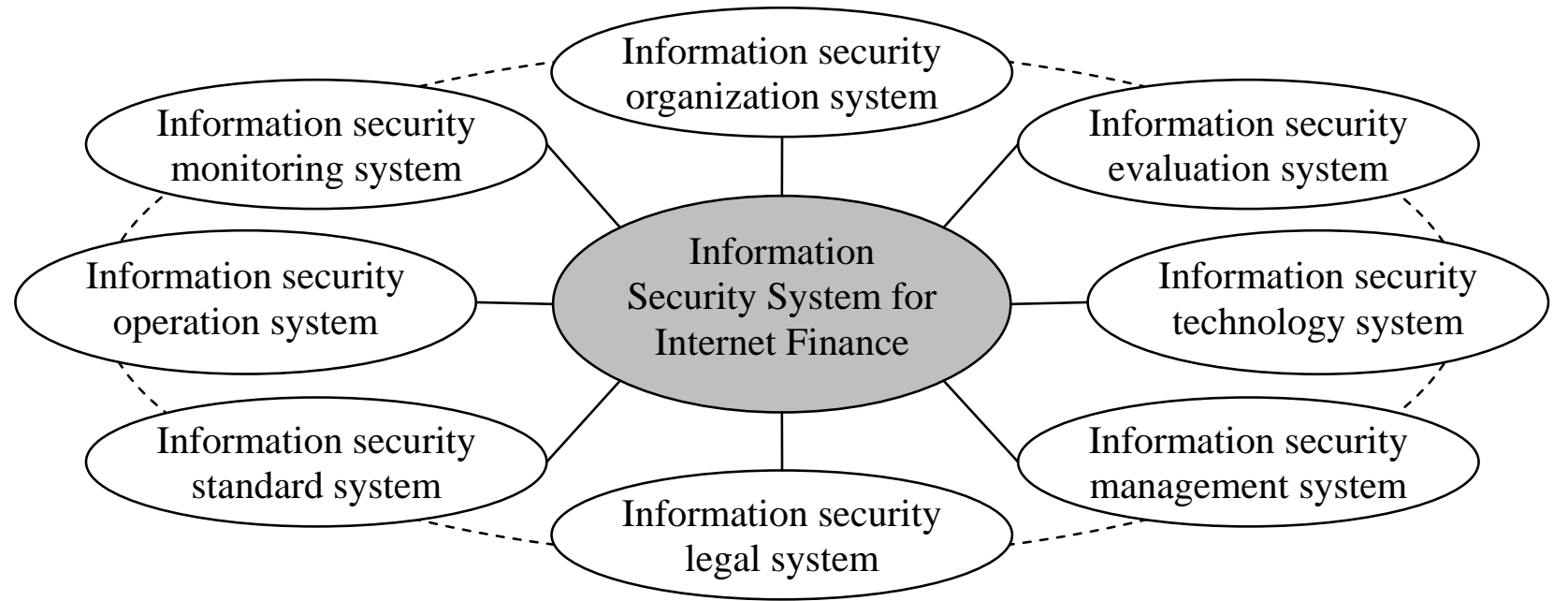

Fig. 2. Information security system for internet finance

(1) Information security organization system. Establish a horizontal coverage of all departments and individuals related to Internet financial applications, vertical and horizontal through all levels of the implementing agencies of the Internet financial information security organization system. First, the establishment of Internet financial information network security decision-making and leading bodies to determine the important issues of information security, the organization of information security work regulations and systems; Second, the establishment of information security work is responsible for the implementation of the organization, guidance, supervision, coordination and Regulate the daily work of information security.

(2) Information security evaluation system Based on the relevant information security technology and management standards, the Internet financial system, as well as its processing, transmission and storage of data confidentiality, integrity and availability of security attributes to assess the process of. By assessing the threats to the system and the potential for the use of vulnerability to the security incident and the consequences of the security incident. Including risk identification, risk analysis and risk assessment.

(3) Information security technology system consists of four levels, including physical security technology, reflected in the reliability of communication lines, software and hardware equipment security, equipment, operating environment, etc .; system security technology, embodied in the Network security technology, including identity authentication, access control, confidentiality of 
data transmission, domain name security, etc .; application of security technology, mainly by the use of services provided by the application system software and data The safety of the generation.

(4) Information security management system is the soul of information security, consists of three parts: First, the legal management, according to laws and regulations on the Internet financial entities and their relationship with the outside world norms and constraints; Is the system management, based on security needs to develop a series of internal rules and regulations; Third, training management, is to ensure the premise of information security.

(5) Information security legal system. The legal system is composed of all the existing laws, which is formed by the combination of legal departments. It is the organic unity of objective rule and subjective attribute, which requires strict structure And internal coordination. At present, China's information security laws and regulations system initially formed, but there are few laws and regulations, the lack of information security basic law, especially specifically for the Internet financial legal system needs to be further improved.

(6) Information security standard is the technical support of information security system construction. It is an important tool for safeguarding national interests and safeguarding national security. Under the leadership of the National Standardization Committee, the Ministry of Industry and Information Technology, with the strong support of relevant departments such as the Ministry of Public Security, the Ministry of Security, the State Secrecy Bureau and the Cryptographic Administration Bureau, a large number of national standards for information security have been formulated and information security Standard system for the healthy development of the Internet financial industry to provide support.

(7) Information security operation system, including infrastructure operation and maintenance services, system operation and maintenance services and system operation support services. Infrastructure maintenance service refers to the basic environment, hardware, basic software fault diagnosis and repair; system operation and maintenance services is through the use of monitoring and service management tools, etc., to ensure the normal operation of the system. System operation support services are services that enhance service effectiveness, provide assessment, data management, data analysis, and business process management.

(8) Information security monitoring system. Ensure that the outputs generated by the safety assessment and control subsystem are implemented and monitored, including coordination with other systems, to conduct safety event correlation analysis to identify new security risks that the system may face, to ensure the implementation of safety management, Implement centralized management of security policies, system configuration, and security event analysis. The safety monitoring process is shown in Fig. 3.

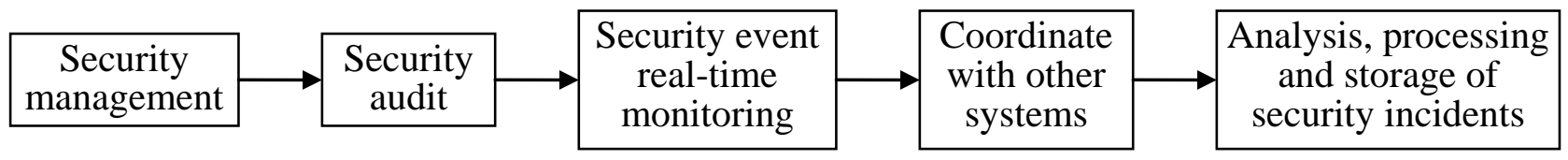

Fig. 3. Safety monitoring system of internet finance

\section{Strategies on Information Security for Internet Finance}

According to the Internet financial information security system, based on the relevant literature [9,10], put forward to protect the Internet financial information security strategy is as follows:

(1) To strengthen information risk monitoring. The development of the Internet, so that financial transactions broke through the traditional financial business of time and space, the transaction object can not be clear, the transaction efficiency continues to increase, increasing the difficulty of on-site inspection, resulting in the importance of off-site inspection continue to show. Therefore, in order to achieve the purpose of timely monitoring the information security risks arising from the Internet financial process, it is necessary to strengthen the supervision of the funds paid by the third party, strengthen the market constraints, establish and optimize the third party payment mechanism, 
fund custody mechanism and capital supervision mechanism Information Management of Internet Finance.

(2) To take effective financial information security precautions. First, to strengthen and improve the financial information security legal system, learn from foreign successful experience, the development of Internet financial payment transaction legitimacy, security technology confidentiality and other laws and regulations; Second, to strengthen the Internet financial supervision in the field of information security international cooperation to improve their own The third level is to further improve the financial information system security audit system, a comprehensive clean-up of the existing computer security system, improve the financial information system security audit management to prevent the system. Third, to further improve the financial information system security audit system,

(3) To take technical means to protect data storage security. First, data encryption. Implement movement protection between data set nodes and applications. Application privacy protection and outsourcing data calculation, shielding network attacks. Second, separate the key and encrypt the data. At the same time, define the key management life-cycle of generation, storage, backup and recovery. Third, use the filter. Through monitoring, found that the data left the user network, it automatically prevents the transmission again. Fourth, the data backup. Through the system disaster recovery and sensitive information centralized control, to achieve end-to-end data protection, to ensure that the data suffered damage, the backup data is still available.

(4) Improve the top of the information security system design. The financial information security system established on the basis of the original financial information is mainly for the traditional financial information security such as key management, identity recognition and core data access control, and is not well prepared for the rapid rise of Internet finance. Facing the new situation, we should establish the active defense system of Internet financial security as soon as possible, establish the information security service guarantee alliance at the national level financial and security department, and perfect the existing financial information security organization security system. Including the rapid development of Internet finance laws and regulations, intellectual property technology, personnel and social credit system and so on.

\section{Conclusion}

Internet finance as a new form of financial, it is necessary to maintain a moderate positive attitude to encourage innovation, but also on the information security risks to develop appropriate regulatory measures to promote innovation and regulation, efficiency and fair balance of coordinated development. Internet financial information security risk control, both the national macro-level policy support and guidance, but also need financial institutions, Internet companies and investors and other joint efforts. Only to maintain the Internet financial information security risks of high vigilance, always concerned about the development of information security technology, timely tracking and master the latest Internet technology development trend at home and abroad in order to obtain the initiative in the information security management, effectively avoid the information brought about by the Internet Security risks, and better promote the sustainable, healthy and steady development of Internet finance, and better serve the real economy.

\section{References}

[1] S. J. Wei, M. Wei, " Supervision and control of Internet financial information security," Financial Computer of China, vol. 28, no. 8, pp. 65-69, 2016.

[2] J. B. Hu, S. Song, F. Shi, "The Information Security Risks \& Prevention of Internet Finance," Credit Reference, vol. 33, no. 4, pp. 13-17, 2015.

[3] R. Xu, "Research on network financial security and risk control," Commercial Times, vol. 31, no. 6, pp. 78-79, 2012. 
[4] Thesis net, "Internet Banking: status quo, risks and countermeasures," http://www.xzbu.com/2/view-6817973.htm, 2017-6-2.

[5] Docin, "Introduction of national standard system for information security," http://www.docin.com/p-1352316721.html, 2017-6-2.

[6] Baidu Wenku, "Brief analysis of legal system of information security in China," https://wenku.baidu.com/view/0cdf75d528ea81c758f57859.html, 2017-6-2.

[7] China Life Insurance Limited by Share Ltd, "Construction of information security management framework for insurance enterprises," Financial Computer of China, vol. 24, no. 8, pp. 18-22, 2012.

[8] P. F. Wu, "Construction of information security system framework of online banking," Journal of Northwest University(Philosophy and Social Sciences Edition), vol. 40, no. 2, pp. 34-38, 2010.

[9] B. B. Zhang, "Research on financial information security countermeasures in Internet Financial Era," Financial Technology Time, vol. 34, no. 7, pp. 66-68, 2015.

[10] Z. W. Zheng, "Information security risks and countermeasures under the background of internet financial times," Computer Knowledge and Technology, vol. 10, no. 13, pp. 2953-2954, 2014. 